\title{
PATHOLOGY OF FOWL TYPHOID AND MOLECULAR DETECTION OF ITS PATHOGEN
}

\author{
J. Hosen ${ }^{1}$, M. M. Rahman' ${ }^{1}$ J. Alam ${ }^{1}$, Z. C. Das' ${ }^{2}$ M. A. H. N. A. Khan ${ }^{3}$ and M. G. Haider ${ }^{1 *}$
}

\begin{abstract}
Salmonellae are important group of pathogens responsible for human and animal diseases. The present study was undertaken with the aim to study pathology of fowl typhoid caused by Salmonella entarica subsp. enteric serovar Gallinarum and to identify Salmonella serovars by polymerase chain reaction (PCR) based molecular method isolated from commercial layer, broiler and sonali chickens of Gazipur district, Bangladesh. A total of 150 cloacal, intestinal and liver swab samples were collected in sterie nutrient and tetrathionate broth from apparently healthy, sick and dead chicken the necropsy. Organ samples were collected in $10 \%$ buffered neutral formalin. The collected tissues were fixed, processed, sectioned, stained with hematoxylin and eosin (H\&E) and examined at low and high power microscopic fields. Grossly, the liver appeared larger and hemorrhagic with focal necrosis. Catarrhal inflammation on intestinal mucosa was seen. The ova were deformed, discolored and cystic. Microscopically, focal necroses with the infiltration of mononuclear cells were seen with congestion of the central vein. Spleen showed severe depletion of lymphoid cells in white pulp along with reticuloendothelial cell hyperplasia. The section of ovary showed deformed ova with hemorrhages. Samples were subjected to various cultural, biochemical, and molecular examinations and the prevalence was identified $28 \%$ cases. Isolated bacteria appeared gram (-)ve, and arranged in short chain. PCR was performed targeting invA gene of Salmonella Gallinarum and amplified 184-bp fragment of the isolates confirmed specific infectivity.
\end{abstract}

Keywords: Fowl typhoid, chickens, Salmonella, pathology, molecular detection.

\section{Introduction}

Poultry is an important component in livestock sector in Bangladesh. In many countries poultry is the principal source of economics and high quality human foods. However, it is a highly sensitive and risk oriented venture. It plays a significant role in poverty alleviation and economic development of Bangladesh. Approximately $70.4 \%$ of total animal protein supplied in the country is contributed by poultry meat (Rahman et al., 2017). To satisfy market demands for poultry meat and eggs by the mostly urban, municipal and rural populations, commercial layer farming with high yielding strains of chickens has expanded rapidly in different areas in Bangladesh. However due to this disease, the producers are facing numerous problems in farm operations and management (Arbelot $e t$ al., 1997).

${ }^{1}$ Department of Pathobiology, ${ }^{2}$ Department of Gynecology, Obstetrics \& Reproductive Health Bangabandhu Sheikh Mujibur Rahman Agricultural University, Gazipur 1706, ${ }^{3}$ Department of Pathology, Bangladesh Agricultural University, Mymensingh, Bangladesh. *Corresponding author: ghaider@bsmrau.edu.bd 
Poultry is essential not only for the national economy of Bangladesh but also the welfare of human beings. Several constraints such as the diseases, poor husbandry, low productivity and high price of feed affect the optimal performance of this industry in Bangladesh (Haque et al., 1991; Rashid et al.,2013).

Fowl typhoid (FT) is an acute infectious enteritis (Okwori et al., 2007) causing heavy mortality in growers or adult chickens although chicks can be affected (Jordan and Pattison, 1992). It is caused by the bacterium Salmonella enteric serovars Gallinarum (Jordan and Pattison, 1992 and Aiello, 1998), a member of the family enterobacteriaceae which is widely distributed throughout the world (Roa, 2000). Salmonella enteric serovars Gallinarium is highly adapted and seldom causes significant problems in hosts other than chickens, turkeys and pheasants (Jordan and Pattison, 1992; Aiello, 1998; Mdegela et al., 2000; Okwori et al., 2007).

The disease occurs sporadically or enzootically in most countries in the world including Bangladesh. FT losses often begin at hatching time and losses continue to laying age (Shivaprasad, 1997). Salmonella. Gallinarum is very important in poultry health because they are responsible for massive destruction of poultry (Gast, 1997). FT seriously threatened the poultry industry in the early 1900 s due to widespread outbreaks accompanied by high mortality (Shivaprasad, 2000). Fowl typhoid is one of the major constraints of poultry industry in Bangladesh (Das et al., 2005). The disease is considered as OIE, list B disease (Calnek et al., 1997). Considering the above facts, the present study was designed to study the clinical signs, gross and histopathological lesions of fowl typhoid along with isolation and identification of Salmonella organism from commercial chickens by biochemical and PCR-based methods.

\section{Materials and Methods}

In this study a total of 50 cloacal swab samples from commercial broiler/layer chickens, 50 liver swab samples and 50 intestinal samples from apparently sick or dead chickens were subjected to bacteriological isolation, identification, histopathological study and molecular diagnosis of Salmonella Gallinarum. The study was performed at the Department of Pathobiology at Bangabadhu Sheikh Mujibur Rahman Agricultural University (BSMRAU) and National Institute of Biotechnology (NIB), Savar, Dhaka.

\section{Collection of samples}

Dead and diseased chickens suspected to bacterial infection were collected from different commercial layer and broiler farms of Gazipur district. Samples were collected from the same flock along with the necropsy study. Using septic cotton swabs, all the cloacal samples were collected in test tubes containing $10 \mathrm{ml}$ tetrathionate broth (TTB) according to methods described elsewhere (Haider et al., 2008).

\section{Cultural and biochemical tests}

All the bacteriological samples were incubated for 24 hours in TTB. Then, all the samples were primarily cultured in Nutrient agar and then subcultured on the SalmonellaShigella (SS) agar, Triple sugar iron (TSI) agar, Brilliant green agar (BGA), Eosine 
methylene blue (EMB) agar (Haider et al., 2008). The presumptive colonies of different bacteria in various media were characterized microscopically using Gram's stain. Five basic sugars such as glucose, sucrose, lactose, mannitol and maltose were used for sugar fermentation test (Haider et al., 2008). Motility test were performed forth separation of motile and non-motile bacteria according to the method described elsewhere (Haider et al., 2008).

\section{Histological study of tissue samples}

Tissue samples collected from intestine, liver, lungs, heart, ovary and different other organs were collected and fixed in $10 \%$ neutral buffered formalin and further processed for histopathological examination (Mashkoor et al., 2013).

\section{Photomicrography}

Photomicrography was taken using photo micrographic camera (ZEISS AxioCamERc5s) facilitated by Department of Gynecology, Obstetrics and Reproductive Health, BSMRAU.

\section{Detection of Salmonella Gallinarum by Polymerase chain reaction (PCR)}

From liver, lungs and other tissue samples the genomic DNA of Salmonella Gallinarum were extracted using DNA extracting kits (Promega Corp. Madison, WI, USA). (Haider et al., 2009). Extracted DNA amplification was carried out using primers specific for the gene invA byusing commercial PCR kits in a thermocycler (Gene amplification PCR system 9600, eppendorf, Germany). PCR reaction mixture and PCR conditions were same as described elsewhere (Haider et al., 2009). Amplified products were separated by gel electrophoreses on $1.5 \%$ agarose gel containing $5 \mu \mathrm{g}$ per $\mathrm{ml}$ ethedium bromide with a100bp ladder as molecular weight marker

\section{Results and Discussion}

Prevalence of isolated and identified organisms

A total of 150 samples were collected during the study period. The bacterial flora isolated from the cloaca, liver and intestine of healthy and sick/dead poultry are shown in the Table 1. The cloacal samples were taken from both live and dead chickens whereas internal organ samples were taken only from dead/ sick chickens. The prevalence of Salmonella Gallinarum was found in $28 \%$ cases, which was confirmed by different sugar fermentation and biochemical tests. This result is lower than the reports of other authors (Jordan and Pattison, 1996; Jones et al., 2001)

In case of commercial layer, among 117 samples tested, 39(33.33\%) were positive for Salmonella and in case of sonali chickens $3(16.67 \%)$ were positive for Salmonella from 18 samples where as all samples (15) collected from broiler chicken were negative for Salmonella (Table 2).

\section{Clinical signs}

The affected chickens exhibited drowsiness, weakness, loss of appetite, ruffling feathers, poor growth, labored breathing, attendant cytoseparate from healthy chikens and sometimes greenish-yellow diarrhea were observed. The adult affected chickens showed depression, anorexia, diarrhea and dehydration. There was found the drop of feed consumption 
Table 1. Salmonella Gallinarum isolated from different organs $(n=150)$ of chickens

\begin{tabular}{|c|c|c|c|c|c|}
\hline \multirow{2}{*}{ Swabs\# } & \multirow{2}{*}{\multicolumn{2}{|c|}{ Total number of samples }} & \multicolumn{2}{|c|}{ No. of positive cases } & \multirow{2}{*}{$\%$ of positive cases } \\
\hline & & & & Total & \\
\hline \multirow[t]{2}{*}{ Cloacal } & Healthy & 75 & 9 & \multirow[b]{2}{*}{42} & 28 \\
\hline & Sick/Dead & 75 & 33 & & \\
\hline \multirow[t]{2}{*}{ Intestinal } & Healthy & - & - & \multirow[b]{2}{*}{33} & 44 \\
\hline & Sick/Dead & 75 & 33 & & \\
\hline \multirow[t]{2}{*}{ Liver } & Healthy & - & - & \multirow[b]{2}{*}{33} & 44 \\
\hline & Sick/Dead & 75 & 33 & & \\
\hline \multicolumn{6}{|c|}{$\begin{array}{l}\text { (\#Cloacal swabs were taken from both live and dead chickens where as intestine and liver swabs wer } \\
\text { taken only from dead/sick chickens) }\end{array}$} \\
\hline \multicolumn{6}{|c|}{$\begin{array}{l}\text { Table 2. Prevalence of Salmonella } \\
\text { chickens }(n=150)\end{array}$} \\
\hline \multicolumn{2}{|c|}{$\begin{array}{ll}\text { Type of poultry } & \text { No. of case }\end{array}$} & \multicolumn{2}{|c|}{ No. of positive cases } & \multicolumn{2}{|c|}{$\%$ of positive cases } \\
\hline \multicolumn{2}{|c|}{ Broiler } & \multicolumn{2}{|c|}{0} & \multicolumn{2}{|c|}{0} \\
\hline Cock (Sonali) & 18 & \multicolumn{2}{|c|}{3} & \multicolumn{2}{|r|}{16.67} \\
\hline Layer & 117 & \multicolumn{2}{|c|}{39} & \multicolumn{2}{|r|}{33.33} \\
\hline
\end{tabular}

Lane 1: Negetive control (NC), Lane 2-6: Showing 284bp band specific for invA gene of Salmonella.

was seen in all the infeceted chickens and appeared similar with the findings of previous authors (Watkins et al., 2003; Haider et al., 2008; Saha et al., 2012; Ogie et al., 2013; Dutta et al., 2015 and Unze et al., 2017).

\section{Gross lesions}

Grossly, the liver appeared swollen, congested along with bronze discoloration and in few cases liver revealed hemorrhages and focal necrosis (Fig. 1a) found similar with the previous findings of Calnek et al. (1997); Madhuri and Sadana (2005) and Saha et al. (2012). The cardiac lesions consisted of mild to moderate congestion and petechial hemorrhage in the base of the heart. In few cases, multiple white nodules with distorted shapes were observed (Fig. 1b). Ogie et al. (2013) and
Uneze et al. (2017) also reported similar findings. Spleenomegaly along with multiple necrotic foci on the surface of the spleen was found. Pinpoint hemorrhages were seen in the spleen (Fig. 1c) and kidney. Lungs were highly congested with pneumonic lesions. The ova were deformed, discolored and cystic (Fig. 1d). The observation of this study was supported by the findings of Madhuri and Sadana (2005); Beyaz et al. (2010); Garcia et al. (2010); Nazir et al. (2012); Saha et al. (2012) and Uneze et al. (2017). Catarrhal inflammation is a frequent was also evident in some cases characterized by thick slimy mucus exudates on mucosal surfaces in the lumen of intestine (Fig. 1e). The findings were in agreement with the findings of Saha et al. (2012) who found 70.6\% intestine hemorrhagic to catarrhal enteritis while $29.4 \%$ 


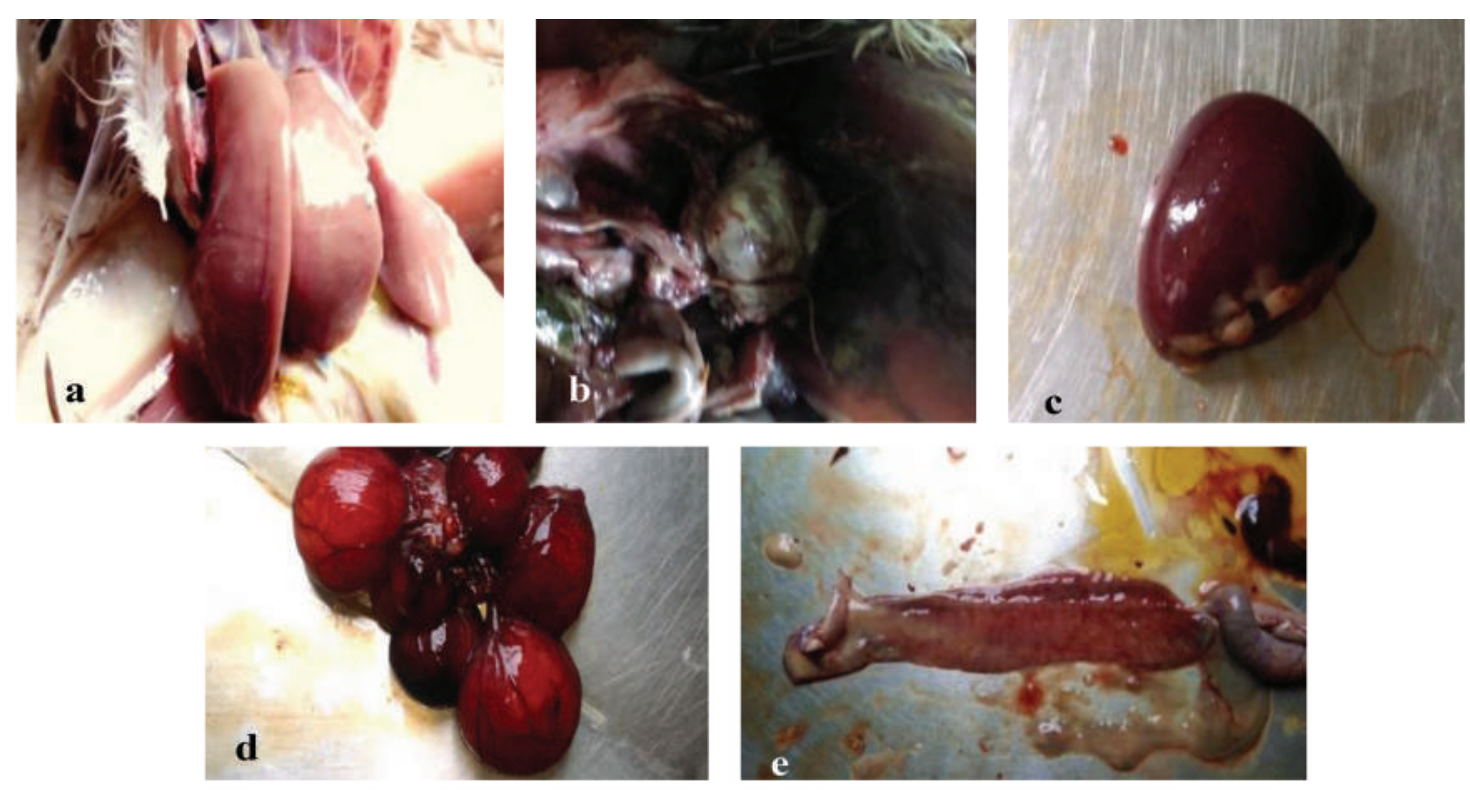

Fig. 1. Gross pathological changes in visceral organs of chickens caused by Salmonella Gallinarum (a) bronze discoloration with enlargement of liver, (b) necrotic nodule on heart, (c) splenomegaly and pin point hemorrhages were seen in the spleen, (d) catarrhal inflammation and thick slimy mucusexudates on mucosal surfaces in the lumen of intestine, (e) ova were deformed, discolored and cystic.

only hemorrhagic and congested which also supported by other authors Madhuri and Sadana (2005); Ogie et al. (2013) and Uneze et al. (2017).

\section{Histopathology}

Microscopically, the hepatitis was characterized by leukocytic infiltration at perivascular areas along with hydropic vacuolation in hepatocytes, multiple necrotic foci noticed with Kupffer cell hyperplasia. The section of livers showed congestion, hemorrhages, focal degeneration, focal necrosis with infiltration of mononuclear cells and round cells and congestion of the central vein (Fig. 2a). Such histopathological study of liver were supported by Calnek et al. (1997); Hossain et al. (2006); Nwiyi and Omadamiro (2012) and Joshua et al. (2015).
Section of the hearts showed severe degeneration and fragmentation of muscle fibers (non suppurative myocarditis) with leukocytic infiltration (Fig. 2b). Fibrinous pericarditis with infiltration of heterophils, lymphocytes and macrophages was also observed in some cases. Spleen showed necrosis of lymphoid follicles leading to severe depletion of lymphocytes in white pulp along with reticuloendothelial cell hyperplasia (Fig. 2c). Lungs showed diffuse congestion and hemorrhages. Haemorrhage was also seen inthe alveoli (red hepatization). Depletion of sero-fibrinous exudate was seen in lung alveoli and inter-lobular septa (Fig. $2 \mathrm{~d})$. The section of ovary showed different shaped ova with hemorrhages (Fig. 2e). These histopathological findings were in agreement 

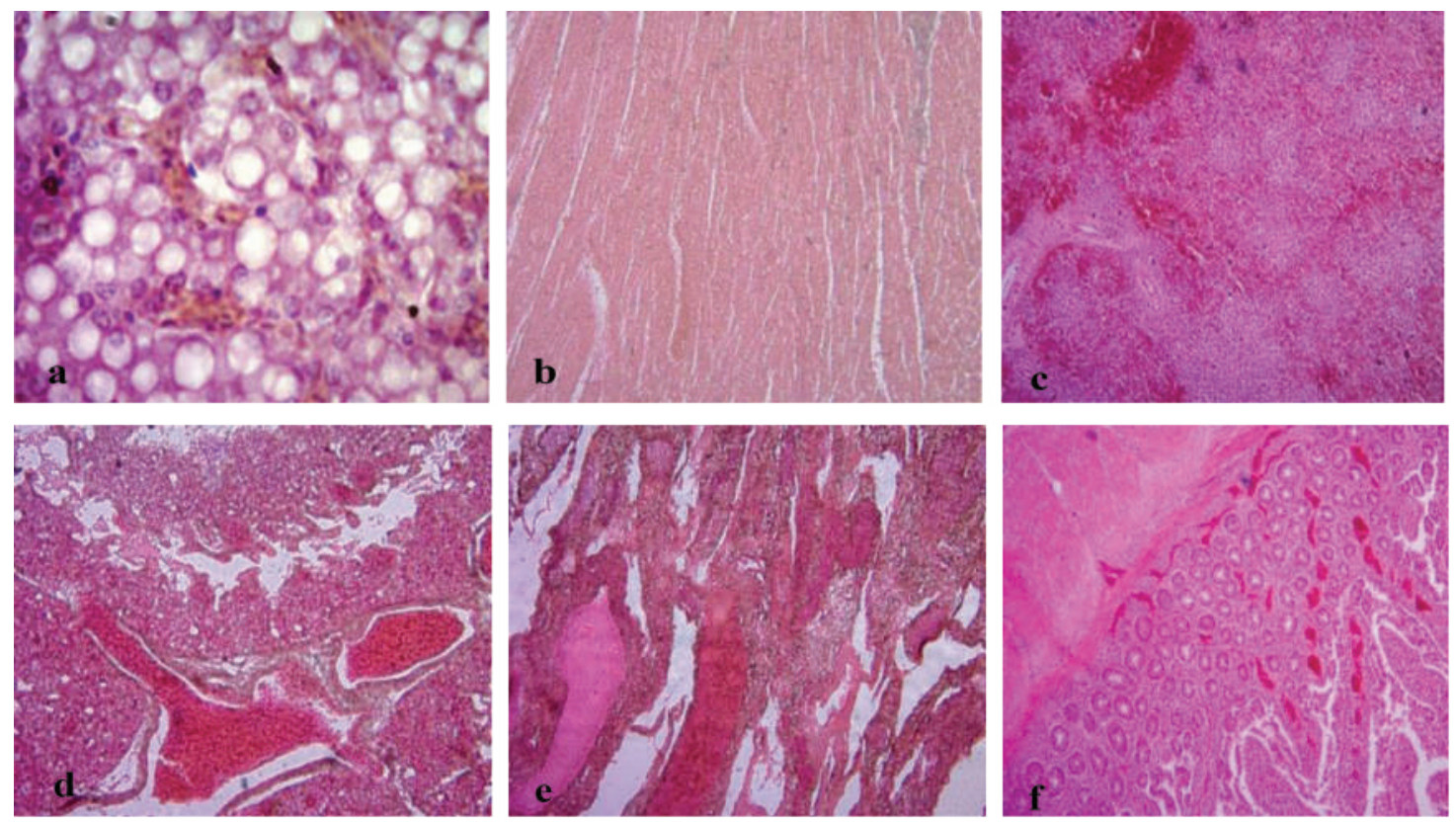

Fig. 2. Hispathological changes in different organs of chickens caused by Salmonella Gallinarum, (a) section of liver showing vacular degeneration and necrosis of hepatocytes, (H \& E, X 100), (b) section of heart showing scatteredly distribution of more acidophilic muscle fibers with few heterophils and round mononuclear cells among the muscle fibers, (H \& E, X 100), (c) section of spleen showing focal degeneration and necrosis of lymphocytes (H \& E, X 40), (d) section of intestine showing hemorrhage and infiltration of inflammatory cells, (H \& E, X 40), (e) section of ovary showing different shaped ova with hemorrhage, ( $H \& E, X$ 40), (f) section of lungs showing severe congestion, infiltration of heterophils and pink color exudate in alveoli, (H \& E, X 40).

with Garcia et al. (2010); Ogie et al. (2013); Joshua et al. (2015) and Uneze et al. (2017).

The section of the intestine showed desquamation of mucosal epithelium resulting in denuded villi and lumen was filled with necrotic mass, congestion, hemorrhage sand infiltration of inflammatory cells (Fig. 2f). These findings were supported by the result of Saha et al. (2012) who reported that 47.1\% infiltration of heterophils and lymphocytes in the mucosa. The predominating cells in inflamed intestinal mucosa due to FT are heterophils and lymphocytes (Hossain et al., 2006; Nwiyi and Omadamiro, 2012).

\section{Colony morphology}

On Salmonella-Shigella (SS) agar, all the isolates produced translucent, black, smooth, small round colonies which are positive for Salmonella Gallinarum. All the suspected Salmonella isolates produced pink color colony with black centre (Fig. 3a). Black colonies were produced on Xylose Lysine Deoxycholate (XLD) Agar medium from isolated Salmonella organism (Fig. 3b). White colonies were produced on Nutrient Agar (NA) medium from isolated Salmonella organism (Fig. 3c). Black colonies were produced on TSI medium from isolated Salmonella 

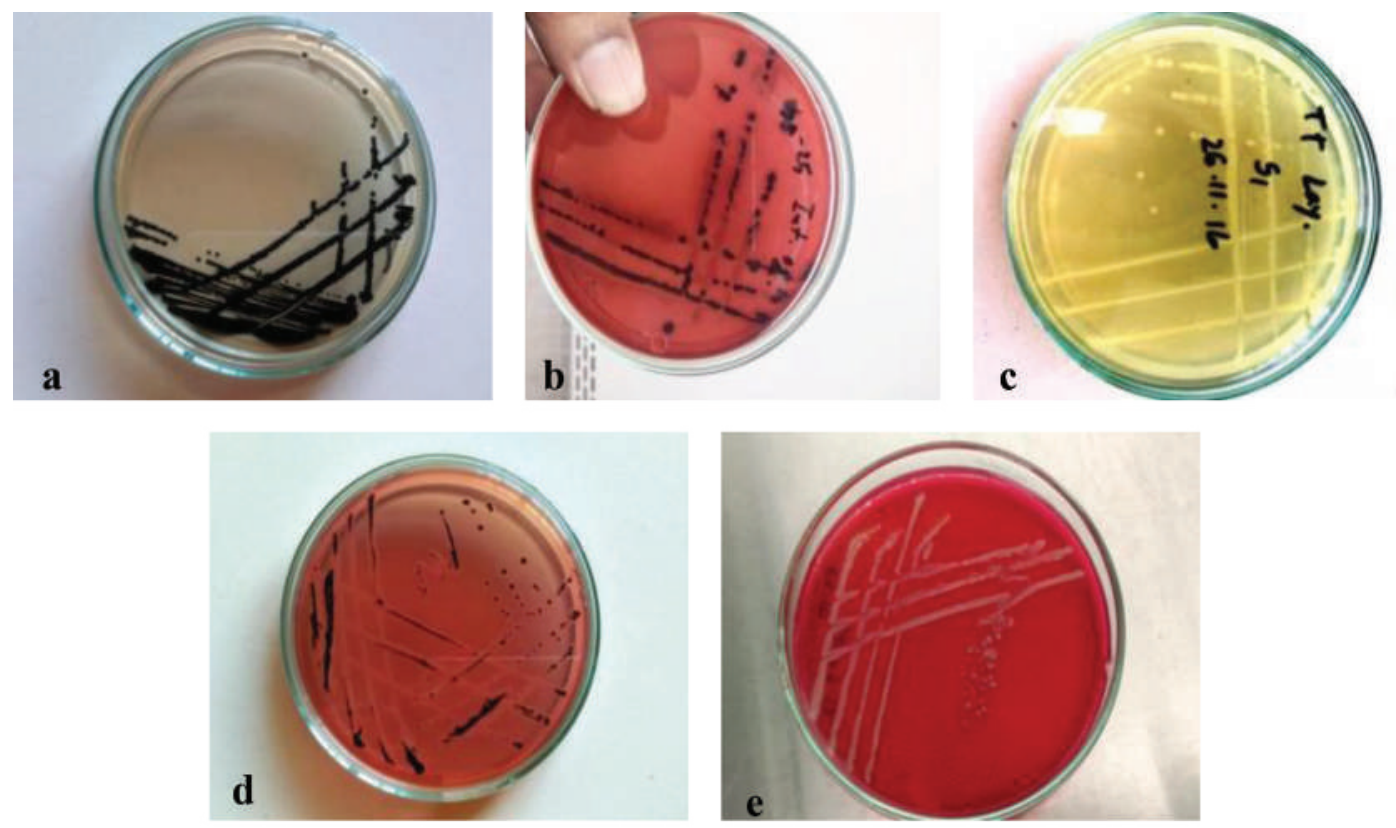

Fig. 3. Colony characters of Salmonella Gallinarumin different agar medium, (a) production of black colonies on Salmonella-Shigella (SS) Agar medium, (b) production of black colonies on Xylose Lysine Deoxycholate (XLD) Agar medium, (c) production of white colonies on Nutrient Agar (NA) medium, (d) production of black colonies on TSI medium, (e) production of white colonies on Brilliant Green Agar (BGA) medium.

organisms (Fig. 3d). White colonies were produced on Brilliant Green Agar (BGA) medium (Fig. 3e). All these were suggestive for bacterial isolate belonging to Salmonella spp. (Sujatha et al., 2003; Muktaruzzaman et al., 2010; Hyeon et al., 2012).

In microscopic examination smears stained Gram's stain revealed gram-negative, non motile, pink colored, short rod shaped bacteria, arranged in single and paired (Fig.4). These findings support the report of Ambily and Mini (2014). Hanging drop preparation of bacterial growth in nutrient broth showed the bacteria non motile belonging to similar others (Grimont et al., 2000).

\section{Results of biochemical tests}

Six of the isolates fermented glucose, maltose, lactose, mannitol and dulcitol with producing acid, which are typical characteristics for $S$. Gallinarum. There was no fermentation of lactose, sucrose and arabinose. Acid production was marked by the color change from reddish to yellow. Gas production was marked by accumulation of gas in the Durham's tube. These results were supported by Hossain (2006) who stated that among five basic sugars the Salmonella ferment dextrose, maltose and mannitol with production of acid and gas but no fermentation was observed in lactose and sucrose. Proux et al. (2002) reported that the biovar Salmonella Pullorum and Salmonella Gallinarum were differentiated by the use of sugars such as maltose, dulcitol and glucose. 


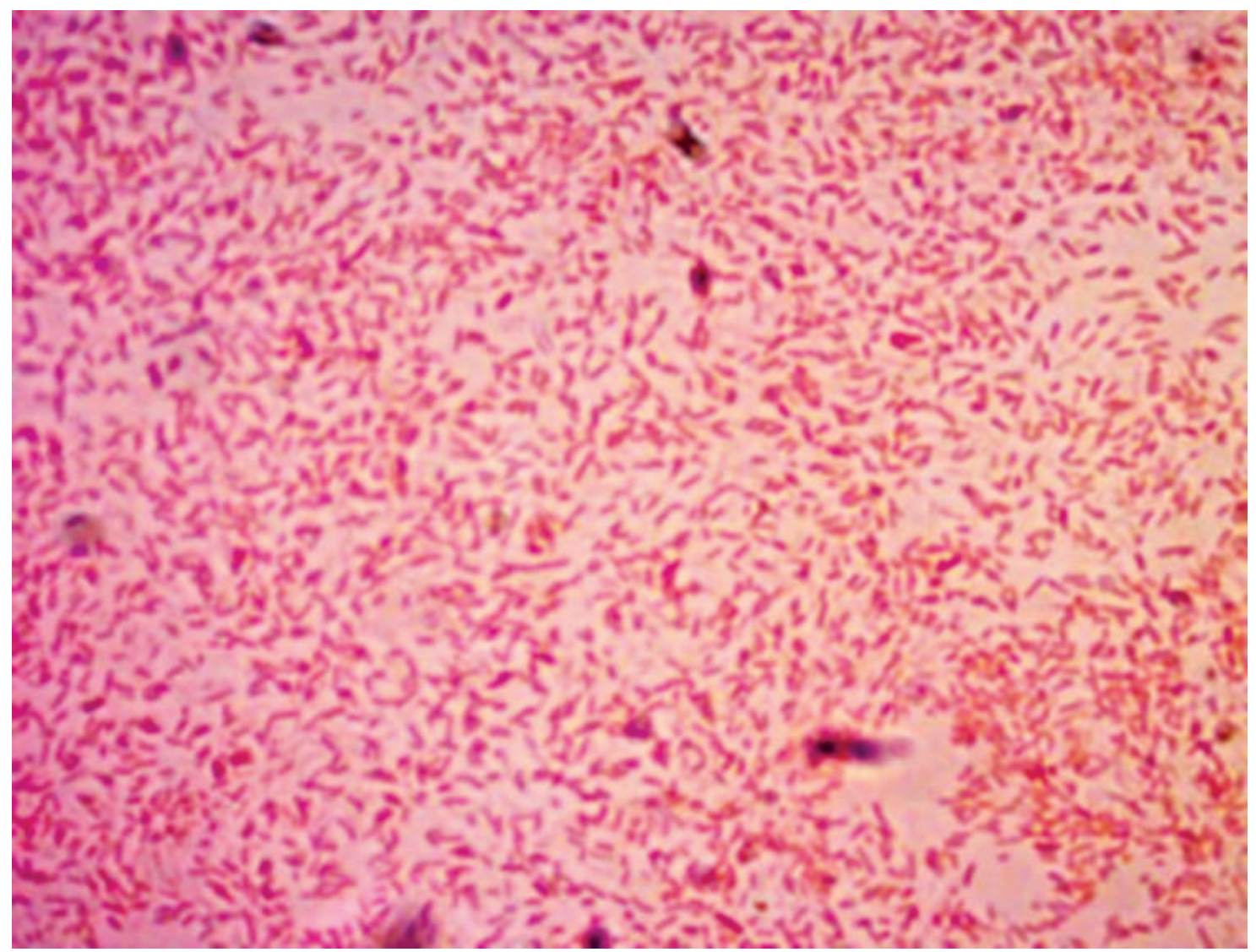

Fig. 4. Isolated Salmonella Gallinarum showing rod shape, short chain forming bacteria, (Modified Gram's stain, $X$ 100).

Molecular detection of $S$. Gallinarum by PCR

Polymerase chain reaction with invA primer, 5 isolates showed positive band at $284 \mathrm{bp}$ i.e. the five (5) isolates were found to be Salmonella Gallinarum. All the Salmonella suspected culture subjected to PCR amplification, generated a product of approximate molecular size 284bp fragment of invA gene (100 specific for Salmonella spp.) 100bp DNA marker was used as a molecular weight marker. The band size detected in all the Salmonella isolates and analyzed by agarose gel electrophoresis (Fig. 5). All conditions and results found in the PCR are supported by the findings of the several authors such as Simone et al. (2009); McClelland et al. (2001); Kisiela et al. (2005); Jawad and Hamadani (2011). Maximum investigators (Guo et al., 1999; Ferretti et al., 2001; Schneder et al., 2002) try to establish a method, which can reduce the periods of Salmonella identification procedures from various samples and they recommended this invA gene for detection of Salmonella. 


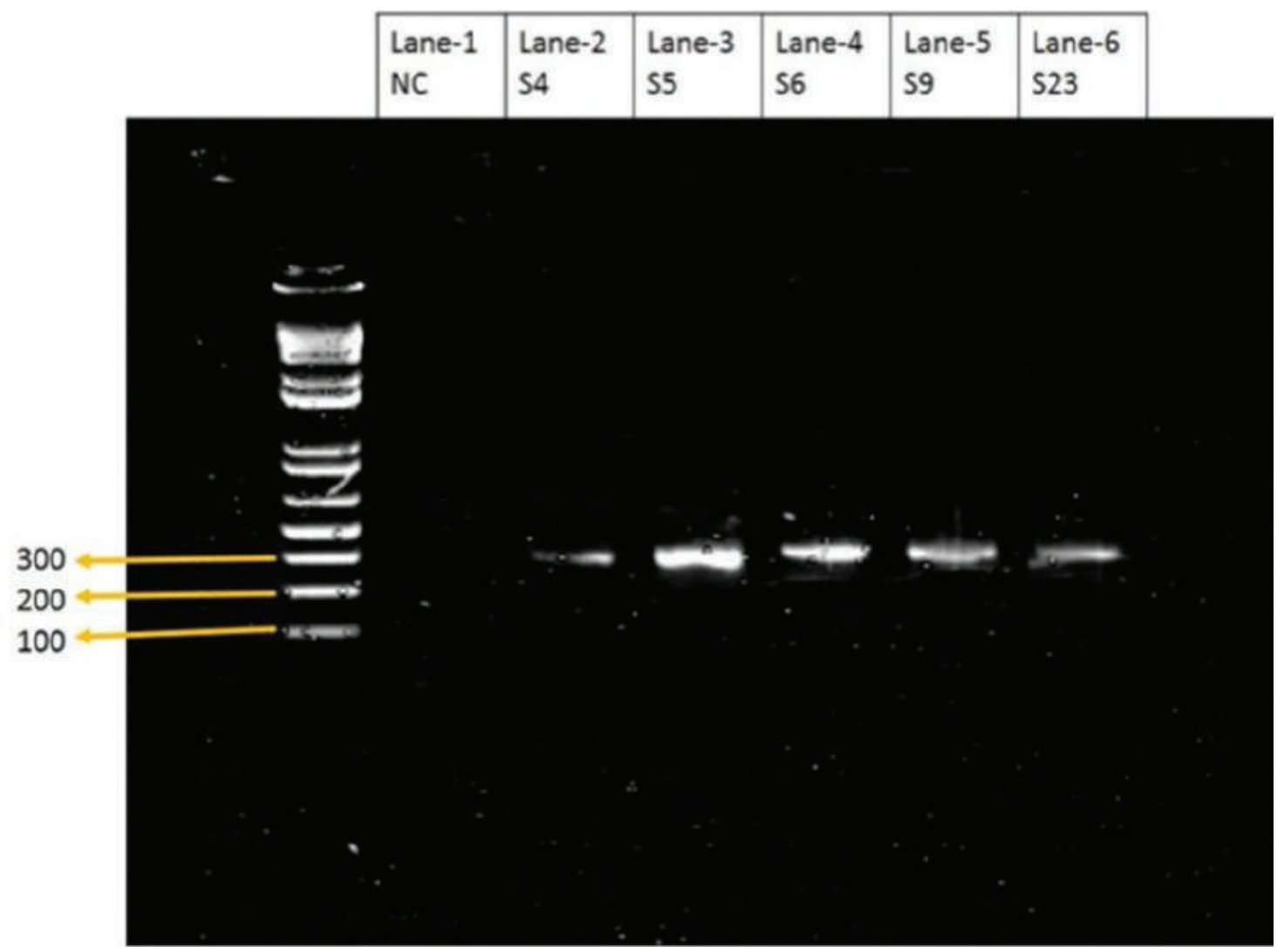

Fig. 5. Agarose gel electrophoresis for visualization of invA gene (284 bp) of Salmonella.

\section{Conclusions}

Salmonella Gallinarum is a causal agent of fowl typhoid. It is a major concern of poultry industry in recent days in Bangladesh. As such, researchers, veterinarians, farmers and the government are working in tandem to search for new method of testing and characterization for Salmonella Gallinarum. Clinical signs, gross lesions, biochemical tests and histopathological lesions study are helpful for the detection of fowl typhoid though there have some contradictions. Howerver, PCR based methods for identifying pathogens provide more advantageous options for this purpose than conventional testing. The
PCR protocol adapted targeting invA gene is specific for Salmonella spp. Therefore PCR methods described here might be used in combination with biochemical study to identify fowl typhoid.

\section{References}

Abdu, P. A. 2007. Manual of Important Poultry disease in Nigeria. $2^{\text {nd }}$ Edition. MacChin Multimedia Designers, Zaria Pp. 42-47.

Agbaje, M. R. Davies, M. A. Oyekunle, O. E. Ojo, F. O. Fasina, and P. A. Akinduti, 2010. Observation on the occurrence and transmission pattern of Salmonella Gallinarum in commercial poultry farms in Ogun State, South Western Nigeria. Afr. J. 
Microbiol. Res. 4(9): 796-800.

Aiello, S. E. (Ed) 1998. The Merck Veterinary Manual, $8^{\text {th }}$ Edition, Merck \& Co., Inc, USA. Pp. 1995-1996.

Ambily, R. and M. Mini. 2014. Salmonellosis in Japanese Qiuails-AReport from central Kerala, India. Int. J. Sci. Res. Vol. 3. Pp 361-362.

Arbelot, B., J. F. Dayon, D. Mamis, J. C. Gueye, F. Tall, H. Samb, 1997. Seroprevalence survey of dominant avian diseases in Senegal: mycoplasmosis, fowl typhoid and pullorum disease, Newcastle, infectious bursal and infectious bronchitis diseases. Rev. Elev. Med. Vet. Pay. 50: 197-203.

Beyaz, L., A. Atasever, F. Aydin, K. S. Gumusoy and S. Abay. 2010. Pathological and clinical findings and tissue distribution of Salmonella Gallinarum infection in turkey pools. Turk. J. Vet. Ani. Sci. 34: 101-110.

Calnek, B. W., H. J. Barnes, C. W. Beard, L. R. McDougald, and Y. M. Saif. 1997. Diseases of Poultry. $10^{\text {th }}$ edition. Iowa State University Press, Ames, Iowa, USA. Pp. 131- 140.

Das, P. M, D. M. M, Rajib, M. Noor, M. R. Islam. 2005. Retrospective analysis on the proportional incidence of poultry diseases in greater Mymensingh district of Bangladesh. In: proceeding of $4^{\text {th }}$ international poultry show and seminar, from February 28 to March 2, 2003, held in Bangladesh-Chaina Friendship Conference Centre, Agargoan, Dhaka. Pp. 35-39.

Dutta, P., M. K. Borah, R. Gangil, and R. Singathia, 2015. Gross/ Histopathological impact of Salmonella Gallinarum isolated from layer chickens in Jaipur and their antibiogram assay. Int. J. Advanced. Vet. Sci. and tech. 4(1): 153-159.

Ferretti, R., L. Mannaazzu, , L. Cocolin, G. Comi, and F. Clementi, 2001. Twelve-hour PCRbased method for detection of Salmonella spp. in food. Appl. Envir. Microbiol. 74: 977-978.
Garcia, K. O., A. M. Santana, O. C. Freitas Neto, Jr. A. Berchieri and J. J. Fagliari, 2010. Experimental infection of commercial layers using a Salmonella enteric serovar Gallinarum strain: blood serum component and histopathological changes. Brazilian. J. Vet. Pathol. 3(2): 111-117.

Gast, R. K. 1997. Salmonella infection. In B. W. Calnek, H. J. Barnes, C. W. Beard, L. R. McDougald, Y. M Saif, editors. Disease of Poultry. $10^{\text {th }}$ edn. Iowa State University Press. Iowa, USA.

Grimont, P. A. D., F. Grimont, and P. Bouvet. 2000. Taxonomy of the genus Salmoenlla. In C. Wray and A. Wray, eds. Salmonella in Domestic Animals, CABI Publishing, Oxon, U.K. Pp. 1-17.

Guo, L., P. B. Killfer and J. D. A. Morris, 1999. Use of arbitrarily primed Polymerase chain reaction to study Salmonella ecology in a turkey production. Poult. Sci. 78: 24-31.

Haider, M. G., E. H. Chowdhury, M. A. H. N. A. Khan, M. T. Hossain and M. S. Rahman. 2008. Experimental pathogenesis of Pullorum disease with the local isolate of Salmonella enterica serovar. Enterica subspecies Pullorum in pullets in Bangladesh. Korean J. Poult. Sci. 35: 341-350.

Haque, M. E., M. A. Hamid, M. A. R. Howleder and Q. M. E. Haque. 1991. Performance of native chicks and hens reared together or separately under rural condition in Bangladesh. Bangladesh Vet. 8: 11-13.

Hossain, M. S., E. H. Chowdhury, M. M. Islam, M. G. Haider, and M. M. Hossain. 2006. Avian Salmonella infection: isolation and identification of organisms and histopathological study. Bangladesh J. Vet. Med. 4: 7-12.

Hyeon, J. Y., J. W. Chon, I. G. Hwang, H. S. Kwak, M. S. Kim, S. K. Kim, I. S. Choi, C. S. Song, C. Park and K. H. Seo. 2012. Prevalence, antibiotic resistance and molecular characterization of Salmonella 
serovars in retail meat products. J. Food. Protec. 74: 161-166.

Jawad, A. A. K. and A. H. A. Hamadani. 2011. Detection of $f i m \mathrm{~A}$ and $f i m \mathrm{C}$ genes of Salmonella isolates by using polymerase chain reaction. J. Basrah. Res. 37(4): 1817-2695.

Jones, M. A., P. Wigley, K. L. Page, S. D. Hulme and P. A. Barrow. 2001. Salmonella pathogenicity island 2 type III secretion system but not the Salmonella pathogenicity island 1 type III secretion system for virulence in chickens. Infect. Immune. 69: 5471-5476.

Jordan, F. T. W. and M. Pattison, 1992. Poultry Disease $4^{\text {th }}$ ed. W. B. Sauder Company Ltd London. Pp. 169-171.

Jordan, T. W. and M. Pattison. 1996. Poultry diseases, $\left(4^{\text {th }}\right.$ edn $)$. Iowa State Press, Ames.

Joshua, B. I., B. J. O. Olabode, O. S. Blessing, F. M. Yakassai, K. P. Rinle, C. D. Chukwu DorisIsioma, R. A. Gambo, A. B. Olatunde, M. G. Davou, A. J. Saidu, O. P. Ademola. 2015. Gross and Histo-Pathological changes in Japanese Quail (Coturnix Coturnix Japonica) experimentally infected with Salmonella Enterica Serovar Gallinarum. Ani. Vet. Sci. 3(3): 84-88.

Khan, M. A. H. N. A., A. S. M. Bari, M. R. Islam, P. M. Das and M. Y. Ali. 1998. Pullorum disease in semi nature chicks and its experimental pathology. Bangladesh Vet. J. 32:124-128.

Kisiela, D., M. Kuczkowski, L. Kiczak, A. Wieliczko and M. Ugorski. 2005. Differentiation of Salmonella Gallinarum biovar Gallinarum from Salmonella Gallinarum biovar Pullorum by PCR-RFLP of the fim $\mathrm{H}$ gene. J. Vet. Med. B. 52(5): 214-218.

Madhuri, D. and J. R. Sadana. 2005. Sequential pathological changes of fowl typhoid in plasmid cured vaccinated and unvaccinated chickens following challenge with Salmonella Gallinarum var Duisburg. Indian J. Vet. Pathol. 29(2): 82-84.
Mashkoor, J. A. K., M. Z. Khan, R. Z. Abbas, M. K. Saleemi and F. Mahmood. 2013. Arsenic induced clinico-hemato-pathological alterations in broilers and its attenuation by vitamin E and selenium. Pak. J. Agric. Sci. 50: 131-138.

McClelland, M., K. E. Sanderson, J. Spieth, S. W. Clifton, P. Latreille, L. Courtney, S. Porwollik, J. Ali, M. Dante, F. Du, S. Hou, D. Layman, S. Leonard, C. Nguyen, K. Scott, A. Holmes, N. Grewal, E. Mulvaney, E. Ryan, H. Sim, L. Florea, W. Miller, T. Stoneking, M. Nhan, R. Waterston and R. K. Wilson. 2001. Complete genome sequence of Salmonella enteric serovar Typhimurium LT2. Nature. 25, 413(6858): 852-856.

Mdegela, R. H., M. G. S. Yongolo, U. M. Minga and J. E. Olsen. 2000. Molecular epidemiology of Salmonella Gallinarum in chickens in Tanzania. Avian Pathol. 29(5): 457-463.

Muktaruzzaman, M., M. G. Haider, A. K. M. Ahmed, K. J. Alam, M. M. Rahman, M. B. Khatun, M. H. Rahman. and M. M. Hossain. 2010. Validation and refinement of Salmonella Pullorum (SP) colored antigen for diagnosis of Salmonella infections in the field. Int. J. Poult. Sci. 9 (8): 801-808.

Nazir, S., K. S. Ahmad, D. M. Maqbool, M. M. Saleem, K. F. Ahmad and A. Amare 2012. Pathology of spontaneously occurring salmonellosis in commercial broiler chickens of Kashmir Valley. J. World's Poult. Res. 2(4): 63-69.

Nwiyi, P. and O. Omadamiro. 2012. Seroprevalence and isolation of chicken infected with Salmonella: Haematological and Pathological Evaluation. J. Ani. Feed Sci. 2(6): 483-487.

Ogie, A. J., A. E. Salako, B. O. Emikpe, E. A. Amosun, S. A. Adeyemo, and P. O. Akinoluwa. 2013. The comparative susceptibility of commercial and Nigerian indigenous chicken ecotypes to Salmonella 
Gallinarum infection. Sokoto. J. Vet. Sci. 11(2): 49-56.

Okwori, A. E., G. A. Hasimil, J. A. Adetunji, I. O. Akaka and S. A. Junards. 2007. Serological survey of Salmonella Gallinarum antibodies in chicken around Jos, Plateau Sate. Nigerian Onl. J. Health Allied. 6: 2.

Parmer, D. and R. Davies. 2007. Fowl typhoid in small back yard laying flock.Vet. Rec. 160: 348

Popoff, M. Y., J. Bockemuhl and L. L. Gheeshing. 2003. Antigenic formulas of the Salmonella Serovars, $8^{\text {th }}$ ed. WHO collaborating centre for reference and research on Salmonella. supplement 2001 (No:45) to the Kauffmann- White Scheme Research in Microbiology, 154: 173-174.

Proux, K., F. Humbert, E. Jouy, C. Houdayer, F. Lalande, A. Oger and G. Salvat, 2002. Improvements required for the detection of Salmonella Pullorum and Gallinarum.The Canadian. J. Vet. Res. 66: 151-157..

Rahman, M. M., K. S. Huque, N. G. Das and M. Y. A. Khan. 2017. Comparative market supply of protein from livestock and fish in the selected Urban areas of Rajshahi district in Bangladesh. Research on Agriculture, Livestock and Fisheries. Vol. 4, No. 1, April 2017: 29-36.

Rashid, M. H., C. Xue, M. R. Islam, T. Islam, Y. Cao. 2013. Alongitudinal study on the incidence of infectious diseases of commercial layer chickens in Bangladesh. Prev. Vet. Med. 109: 354-358.

Reynolds, D. L. 2003. Multi causal enteric diseases. In: Diseases of poultry (ed. Y. M. Saif), Iowa State University Press, Ames. Pp. 1169-1171.

Roa, G. 2000. A Comprehensive Textbook on PoultryPathology.Medical publisher ltd. Pp. 7-10.
Saha, A. K., M. A. Sufian, M. I. Hossain and M. M. Hossain. 2012. Salmonellosis in layer chickens: pathological features and isolation of bacteria from ovaries and inner content of laid eggs. J. Bangladesh Agric. Univ. 10(1): 61-67.

Schneder, A., C. Gronewald, M. Fandke, B. Kurth, S. Barkowski and K. Berghof. 2002. Realtime detection of the genus Salmonella with the light cycler system. Biochemistry. 4: 19-21.

Shivaprasad, H. L. 1997. Pullorum disease and fowl typhoid. In Calnek, B. W, Barnes, H. J, Beard C. W, McDougald, L R, Saif Y M, editors. Disease of Poultry, $10^{\text {th }}$ ed. Iowa State University Press. Iowa, USA.

Shivaprasad, H. L. 2000. Fowl typhoid and pullorum disease. Review of Scientific Technology, Off. Int. Epiz. 19(2): 405-424.

Simone, A., R. Mendes, B. P. Jaqueline, Z. Fábio, V. F. L. Manoel and B. J. Ângelo. 2009. Molecular differentiation between salmonella enteric subsp. enteric Serovar pullorum and salmonella enteric subsp. enteric serovar Gallinarum. Brazilian J. Microbiol. 40: 184-188.

Sujatha, K., K. Dhanalakshmi and A. S. Rao. 2003. Isolation and characterization of Salmonella Gallinarum from chicken. Indian Vet. J. 80(5): 473-474.

Uneze, B. C., I. H. Iheukwumere, C. E. Okeke. 2017. Sequential pathological study of fowl typhoidin experimentally infected chicks. J. Health, Med. and Nursing. Vol. 35. Pp. 118-121.

Watkins, J. R., A. I. Flower and L. C. Grumbles. 2003. "Salmonella organism in animal feed products used in poultry feed". J. Sci. 3: 290-301. 